\title{
The Mannose-Binding Protein Sm60 from Schistosoma mansoni Suppresses T Cell Proliferation via Inhibition of Interleukin-2 Production
}

\author{
Arlete A. M. Coelho-Castelo ${ }^{1, *}$, Ademilson Panunto-Castelo ${ }^{2}$, Alan Berlese ${ }^{1}$, João S. Silva ${ }^{1}$ and \\ Vanderlei Rodrigues ${ }^{1}$ \\ ${ }^{1}$ Department of Biochemistry and Immunology, School of Medicine of Ribeirão Preto, University of São Paulo, Ribeirão \\ Preto, SP, Brazil \\ ${ }^{2}$ Department of General and Specialized Nursing, College of Nursing of Ribeirão Preto, University of São Paulo, \\ Ribeirão Preto, SP, Brazil
}

\begin{abstract}
Adult worms of Schistosoma mansoni live in the bloodstream, employing immune evasion strategies and exposing few antigens to the immune system. The tegumental surface of adult worms presents Sm60, a mannose-binding protein, which induces neutrophil migration and mast cell degranulation. Here we demonstrated that Sm60 is able to block the in vitro antigen-specific or polyclonal spleen cell proliferation induced by keyhole limpet haemocyanin (KLH) or concanavalin A (Con A), respectively. To address the mechanism of inhibition, we evaluated some cytokines in culture and observed that Sm60 decreased significantly the synthesis of interleukin (IL)-2 induced in response to KLH, but not other cytokines. To block the suppression triggered by Sm60, exogenous IL-2 or $\alpha$-methyl-mannoside were added to KLHstimulated cultures pulsed with Sm60. Only IL-2 abolished the Sm60 effect, suggesting that Sm60 blocked the lymphoproliferation through the inhibition of IL-2 production, in a carbohydrate recognition domain (CRD)-independent mechanism. Our results suggest that Sm60 could participate in the immune evasion mechanisms of $S$. mansoni.
\end{abstract}

Keywords: Schistosoma mansoni, Antigen, Lectin, Sm60, Immunosuppression, Interleukin-2.

\section{INTRODUCTION}

Schistosomiasis is one of the major health problems in 74 developing countries, afflicting at least 200 million people. Another 600 million people are at risk of infection [1]. The etiologic agents, which are trematodes of the genus Schistosoma, establish chronic infections in their hosts in spite of the presence of specific cellular and humoral immune responses. These parasites have evolved a number of immune evasion mechanisms to live in the vasculature of the host, such as shedding of tegument membrane, acquisition of host products onto the tegument to mask its foreign status, molecular mimicry and host immune response inhibitor factors [2].

Lectins are proteins that bind carbohydrates reversibly and with high specificity. They are not enzymatically active on the sugars and are not antibodies but have the ability to recognise molecules inside cells, on cell surfaces, and in physiological fluids $[3,4]$. The wide distribution of lectins among living beings suggests that lectins have important physiological functions. In addition, the great diversity of these proteins regarding structure, carbohydrate-binding specificity and distribution indicates that they may have evolved a variety of distinct roles in different organisms [3-6]. In infection, after the first indication that influenza virus haemagglutinin is responsible for the attachment of

*Address correspondence to this author at the Departamento de Bioquímica e Imunologia, Faculdade de Medicina de Ribeirão Preto, USP, Av. Bandeirantes 3900. 14049-900, Ribeirão Preto, SP, Brazil; Tel: 55-16-3602-4538; Fax: 55-16-3633-6631; E-mail: arlete@fmrp.usp.br the virus to the host cells as a prerequisite for infection, mainly by Alfred Gottschalk in the 1950s [6], many reports have demonstrated that lectins from mammals and several pathogens can have an important function in the infection process [4].

With reference to helminths, there has been little work on the identification and characterization of their lectins. In trematodes, lectin activity has been described in cercarial penetration glands of the avian schistosomes Trichobilharzia szidati and T. regenti $[7,8]$, and fish schistosome Diplostomum pseudospathaceum [9]. The lectin-like protein from D. pseudospathaceum was recently isolated from penetration glands by affinity chromatography with a size of $\sim 24-\mathrm{kDa}$, strongly basic nature and both lectin and enzyme activities [10]. Concerning human schistosomes, Trottein et al. suggested that $S$. mansoni displays selectin-like properties with affinity for the sialyl Lewis $\mathrm{X}\left(\mathrm{Le}^{\mathrm{x}}\right)$ oligosaccharides, providing new insights into the biologic roles of selectins and $\mathrm{Le}^{\mathrm{x}}$-related structures in immunity against helminth parasites [11].

Previously we reported the isolation and characterisation of a D-mannose-binding protein, termed Sm60, from $S$. mansoni tegument. This lectin-like protein was recovered in the mannose-eluted fraction upon affinity chromatography on immobilised mannose of the soluble antigen fraction from adult worm tegument and cercariae. When analysed by SDSPAGE and isoelectrofocusing, Sm60 was detected as a prominent doublet with an apparent molecular mass of $60 / 66-\mathrm{kDa}$ and as a single band with a $\mathrm{pI}$ of 6.9 , respectively. In addition to adult worms, Sm60 was also recognized in preparations of schistosomula extract and soluble egg anti- 
gens using a mouse polyclonal anti-Sm60 serum in immunoblotting assay. This antiserum demonstrated that Sm60 was localised on the tegument of $S$. mansoni adult worms. Sm60 was able to induce in vitro migration of human neutrophils in a dose-dependent manner and in vitro mast cell degranulation, activities that were triggered through its carbohydrate recognition domain (CRD), since these activities were selectively inhibited by $0.2 \mathrm{M}$ D-mannose, but not by $0.2 \mathrm{M}$ D-galactose. Moreover, Sm60 induced in vivo neutrophil migration in rats that was modulated by mast celldependent mechanisms [12].

In the present report, we evaluated the involvement of Sm60 in the induction of immune response. We demonstrated that Sm60 is able to inhibit proliferation and cytokine production by $\mathrm{T}$ lymphocytes under polyclonal (Con A) or specific (KLH) stimulation. Down-regulation was reverted when exogenous IL-2 was added to the culture, suggesting that impaired proliferation was due to decrease of IL-2. The possible importance of this lectin is discussed in the parasite host relationship.

\section{MATERIALS AND METHODS}

\section{Mice and Reagents}

Female BALB/c and $\mathrm{C} 3 \mathrm{H} / \mathrm{HeJ}$ mice, 6-8 weeks old, were bred and maintained under standard conditions in the animal house of the School of Medicine of Ribeirão Preto, University of São Paulo, Ribeirão Preto, Brazil. All animal experiments were performed in accordance with protocols approved by the School of Medicine of Ribeirão Preto Institutional Animal Care and Use Committee (CETEA). RPMI1640 medium, Hepes and keyhole limpet haemocyanin (KLH) were obtained from Invitrogen (Carlsbad, USA), and L-glutamine, 2-mercaptoethanol, penicillin, streptomycin were from Sigma-Aldrich Co. (St. Louis, USA). FCS, concanavalin A (Con A) and recombinant mouse IL-2 (rmIL-2) were purchased from Hyclone (Logan, USA), ICN Pharmaceuticals, Inc. (Costa Mesa, USA) and DNAX Co. (Palo Alto, USA), respectively. rmIFN- $\gamma$, rmIL-10, mAbs to IFN- $\gamma$ (R4-6 A2 and XMG1.2) and IL-10 (AB-417-NA and BAF 417) were obtained from PharMingen (San Diego, USA).

\section{Preparation of Soluble Membrane Proteins from Adult Worms}

S. mansoni (LE strain, Belo Horizonte, Brazil) was maintained by passage through the snail, Biomphalaria glabrata, and BALB/c or Swiss mice. Cercariae were obtained by exposing infected snails to light for $2 \mathrm{~h}$. Adult worms were perfused from mice 8 weeks post-infection (p.i.) and harvested with isotonic saline $(0.9 \% \mathrm{NaCl})$ containing $0.95 \%$ sodium citrate. Five $\mathrm{mL}$ of packed fresh adult worms were suspended in an equal volume of phosphate-buffered saline (PBS, $10 \mathrm{mM}$ sodium phosphate containing $0.15 \mathrm{M} \mathrm{NaCl}$, $\mathrm{pH}$ 7.2) containing $1.7 \mathrm{mM} \mathrm{CaCl} 2,0.9 \mathrm{mM} \mathrm{MgCl}, 1 \mathrm{mM}$ EDTA and $2 \mathrm{mM}$ TLCK (N- $\alpha$-tosyl-L-lysine chloromethyl ketone), and stirred for $30 \mathrm{~min}$ at $37^{\circ} \mathrm{C}$, to release their membranes. After separation, the membrane suspension was treated with precondensed Triton X-114 (final concentration of $0.5 \%$ ), and phase separation was performed as described by Bordier [13]. The detergent phase containing membrane proteins was stored at $-20^{\circ} \mathrm{C}$ until use.

\section{Affinity Chromatography}

Soluble membrane proteins from adult worms (1 mg protein each) were applied to a $2 \mathrm{~mL}$ settled bed of D-mannoseagarose (Pierce, Rockford, USA) at $4^{\circ} \mathrm{C}$. The column was washed with PBS containing $0.5 \mathrm{M} \mathrm{NaCl}$ to release the unbound material, and the bound material was eluted with 0.4 M D-mannose in washing buffer. The bound material was pooled, concentrated and dialysed against sterile PBS using an Amicon stir unit with a 30,000 Mr cut-off YM30 membrane (Millipore Corp., Billerica, USA), and contained less than $0.05 \mathrm{ng} / \mathrm{mL}$ of bacterial endotoxin, as determined by the Limulus amoebocyte lysate assay (Sigma Chemical Co., St. Louis, USA). The Sm60 concentration was determined on the basis of amino acid analysis, which was performed using the phenylthiocarbamyl derivative method [14] after acid hydrolysis with $6 \mathrm{~N} \mathrm{HCl}$ containing $1 \%$ phenol in the vapour phase, at $110^{\circ} \mathrm{C}$ for $22 \mathrm{~h}$. A mixture containing $2.5 \mathrm{nmol}$ of each amino acid [Standard $\mathrm{H}$, (Pierce)] was derivatised and $4 \%$ (100 pmol) was analysed on a Picotag column.

\section{Lymph Node Cell Cultures}

$\mathrm{BALB} / \mathrm{c}$ or $\mathrm{C} 3 \mathrm{H}$ mice (three per group) that were injected subcutaneously in the hind footpad with $100 \mu \mathrm{g}$ either Sm60 or KLH emulsified in CFA. After 11 days, popliteal lymph node (LN) cells were obtained, washed three times in HBSS and adjusted to $2 \times 10^{6}$ cells/mL in RPMI-C [RPMI 1640 containing $2 \mathrm{mM}$ L-glutamine, $50 \mu \mathrm{M} \quad 2$ mercaptoethanol, 100 units $/ \mathrm{mL}$ penicillin, $100 \mu \mathrm{g} / \mathrm{mL}$ streptomycin, and 5\% heat-inactivated FCS (Hyclone)]. To measure antigen-driven cell-proliferative responses, the cell suspension was distributed in 96-well cell culture plates (Corning, Corning, NY) in $200 \mu \mathrm{L}$ culture medium alone or with one of the following stimulating substances: KLH (5 or 10 $\mu \mathrm{g} / \mathrm{mL}), \operatorname{Sm} 60(2.5,5$ or $10 \mu \mathrm{g} / \mathrm{mL})$ or Con A $(2 \mu \mathrm{g} / \mathrm{mL})$. In some experiments, IL-2 (10 ng) or $\alpha$-methyl-mannoside (50 $\mathrm{mM}$ ) (Sigma-Aldrich Co.) were added to the culture. The plates were incubated in a humidified $5 \% \mathrm{CO}_{2}$ atmosphere at $37^{\circ} \mathrm{C}$ for $72 \mathrm{~h}$, and $0.5 \mu \mathrm{Ci}$ of $\left[{ }^{3} \mathrm{H}\right]$ thymidine (NEN, Paris, France) was added for the final $18 \mathrm{~h}$ of culture. The cells were harvested on glass fibre filters (Cell Harvester, Cambridge Technology, Inc., Cambridge, USA) and quantified by a liquid scintillation counter (model LS 6500, Beckman Instruments, Fullerton, USA).

To detect cytokines in supernatants, $\mathrm{LN}$ cell suspension $\left(2 \times 10^{6}\right.$ cells $\left./ \mathrm{mL}\right)$ was distributed in 24 -well cell culture plates (Corning, Corning, NY) in $1 \mathrm{~mL}$ culture medium alone or with $\mathrm{KLH}(10 \mu \mathrm{g} / \mathrm{mL}), \operatorname{Sm} 60(10 \mu \mathrm{g} / \mathrm{mL}), \mathrm{Sm} 60$ and $\mathrm{KLH}(10 \mu \mathrm{g} / \mathrm{mL}$ each) or Con A $(2 \mu \mathrm{g} / \mathrm{mL})$. To detect NO in culture supernatant, LN cells from Sm60-immunised or non-immunized BALB/c mice were stimulated in vitro with Sm60 $(10 \mu \mathrm{g} / \mathrm{mL})$ or Con A $(2 \mu \mathrm{g} / \mathrm{mL})$, respectively. After $48 \mathrm{~h}$ of incubation, the supernatants were harvested by centrifugation and stored at $-20^{\circ} \mathrm{C}$ until ELISA-based cytokine and nitrite assays were performed.

\section{ELISA-based Cytokine Detection Assays}

Culture supernatant cytokine levels of TGF- $\beta$ and IL-2 were determined with a commercial two-site ELISA kits EMax Immunoassay System (Promega Co., Madison, USA) and OptEIA set (Pharmingen), respectively. IFN- $\gamma$ and IL-10 were measured by two-site ELISA using mAbs commer- 
cially available from Pharmingen or R\&D Systems. In brief, 96-well (flat-bottomed) plates (Nunc A/S, Roskilde, Denmark) were coated with anti-mouse cytokine in PBS overnight at room temperature. Free sites were then blocked with block buffer, and supernatants (1:2 diluted) were added and incubated for $2 \mathrm{~h}$ at room temperature. A standard curve was also created with the recombinant cytokine. Cytokine was detected using biotinylated anti-mouse cytokine and horseradish peroxidase-streptavidin. The enzymatic reactions were visualized with a hydrogen peroxide and tetramethylbenzidine substrate (Sigma-Aldrich Co.) and stopped with 1 $M$ sulphuric acid. The absorbances were determined at $450 \mathrm{~nm}$ in a Power Wave X reader (BioTek Instruments, Winooski, USA) and analysed using $\mathrm{KC} 4$ Kineticalc software.

\section{Measurement of Nitrite Production}

The amount of $\mathrm{NO}$ was assessed by determining the concentration of nitrite $\left(\mathrm{NO}_{2}^{-}\right)$accumulated in cell-free supernatants using the colorimetric Griess reaction. Briefly, $50 \mu \mathrm{L}$ of supernatant and serial dilutions of $\mathrm{NaNO}_{3}$ standard solution was placed in 96-well plastic plate, and then mixed with equal volume of Griess reagent ( $1 \%$ sulphanilamide, $0.1 \%$ naphthylethylene-diamide-dihydrochloride, and $2.5 \%$ $\mathrm{H}_{3} \mathrm{PO}_{4}$ ). After incubation for $10 \mathrm{~min}$ at room temperature, absorbance was measured at $540 \mathrm{~nm}$ with a Power Wave X reader (BioTek Instruments, Winooski, USA) and nitrite concentrations were quantified from the standard curve with $\mathrm{NaNO}_{3}$.

\section{Statistical Analysis}

The statistical significance of the differences between means of experimental groups was measured using an unpaired two-tailed Student's $t$ test. Differences which provided $P<0.05$ were considered to be statistically significant. All experiments were performed at least twice.

\section{RESULTS AND DISCUSSION}

Helminths are thought to have developed different strategies for survival in their human host, for instance $S$. mansoni schistosomula compromise complement function [15], degrade host immunoglobulins [16] and consequently weaken a direct immune attack. Besides, S. mansoni may shield itself by molecular mimicry, through acquisition of surface mole- cules from the host, including blood group determinants and MHC molecules, or production of cytokine mimics [17]. These helminths can interact with the adaptive immune response from their hosts by down-regulation of T- and B-cell responses via the induction of regulatory $\mathrm{T}$ cells or the antiinflammatory cytokines IL-10 and TGF- $\beta$ in the chronic phase of infection, as reviewed by Maizels and Yazdanbakhsh [18]. The identification of new tegument proteins is the focus of current research to enhance our understanding of host-parasite interactions $[19,20]$. Because, in our previous work, confocal fluorescence microscopy revealed that Sm60 is located at the tegument of the adult worm stage of $S$. mansoni [12], here we investigated if this molecule could be involved in the induction of immune response. Although the identity of the Sm60 is unknown yet, this protein was reproducibly recovered in the mannose-eluted fraction upon affinity chromatography on immobilised mannose of the soluble antigen fraction from adult worm tegument as a doublet of $60 / 66-\mathrm{kDa}$. Therefore, homogeneous preparation of Sm60 was obtained (data not shown) as described previously [12]. To determine the profile of $\mathrm{T}$ cell immune response after challenge with Sm60, we stimulated in vitro LN cells from Sm60-immunised BALB/c mice in an antigen-specific mode. Sm60 did not induce lymphoproliferation at the concentration of $2.5,5$ or $10 \mu \mathrm{g} / \mathrm{mL}$ (Fig. 1A). When we evaluated the levels of IFN- $\gamma$, IL-2, IL-10, TGF- $\beta$ and NO in the supernatants of the cultures, only IFN- $\gamma(202 \pm 14.1 \mathrm{pg} / \mathrm{mL})$ was detected (Table 1). The proliferative ability of the lymphocytes from LN cells was not compromised, since they proliferated in response to Con A (Fig. 1A). Thus, although Sm60 did not induce the lymphoproliferation in vitro, the IFN- $\gamma$ production suggested that Sm60 could prime lymphocytes in vivo.

Considering that Sm60 could have any suppressive effect on lymphoproliferation, next we investigated its effect on mitogen-driven polyclonal response induced by Con A in LN cells from non-immunised mice. Sm60 at the concentration of $10 \mu \mathrm{g} / \mathrm{mL}$ inhibited about $93 \%$ of the lymphoproliferation (Fig. 1B). Suppressive ability on proliferation of Sm60 was further checked on antigen-specific response by using $\mathrm{LN}$ cells from KLH-immunized BALB/c mice cultured with KLH or KLH plus Sm60. As shown in Fig. (1C), Sm60 in the concentration of 5 and $10 \mu \mathrm{g} / \mathrm{mL}$ suppressed the antigenspecific proliferation of KLH-specific LN cells. Similar to
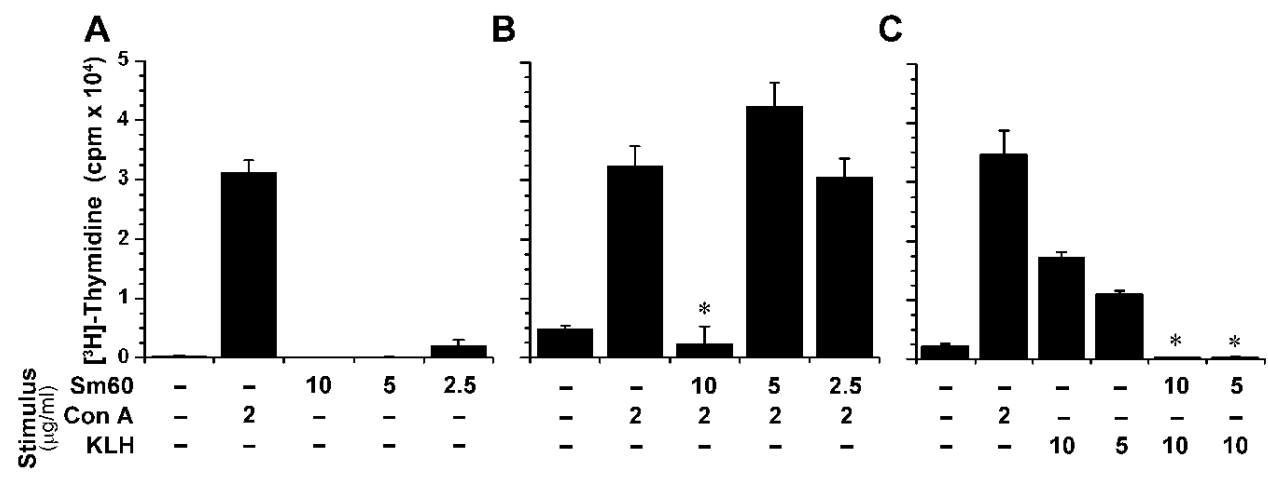

Fig. (1). Sm60 inhibits proliferative response in vitro to polyclonal or specific stimulus. Popliteal lymph node cells $\left(2 \times 10^{6} / \mathrm{mL}\right)$ from BALB/c mice immunised with Sm60 (A), non-immunised (B) or immunised with KLH (C) were cultured with different stimuli, as indicated on the figure, for $72 \mathrm{~h}$. Proliferative response was determined by $\left[{ }^{3} \mathrm{H}\right]$-thymidine uptake. Data are reported as the mean \pm standard deviation for three mice per group preformed in triplicate. Results are representative of two independent experiments. ${ }^{*} P<0.05$ compared to groups stimulated with Con A (panel B) or KLH (panel C). 
Table 1. Production of Cytokines and Nitric Oxide by Lymph Node Cells from Sm60-Immunised BALB/c Mice Stimulated with Con A or Sm60

\begin{tabular}{|c|c|c|c|c|c|}
\hline LN Cells Stimulated with & Nitric Oxide $(\mu \mathrm{M})$ & IL-10 $(\mathbf{p g} / \mathbf{m L})$ & TGF- $\beta(\mathbf{p g} / \mathbf{m L})$ & IFN- $\boldsymbol{\gamma}(\mathbf{p g} / \mathbf{m L})$ & IL-2 $(\mathbf{p g} / \mathbf{m L})$ \\
\hline \hline Con A & $3.5( \pm 0.14)$ & $56( \pm 0.002)$ & $134( \pm 24.2)$ & $367( \pm 7.07)$ & $168( \pm 7.2)$ \\
\hline Sm60 & $<0.9$ & $<15.6$ & $<15.6$ & $202( \pm 14.1)$ & $<7.8$ \\
\hline
\end{tabular}

Popliteal lymph node cells $\left(2 \times 10^{6} / \mathrm{mL}\right)$ from BALB/c mice immunised with Sm60 were cultured for $48 \mathrm{~h}$ with $2 \mu \mathrm{g} / \mathrm{mL} \mathrm{Con} \mathrm{A}$ or $10 \mu \mathrm{g} / \mathrm{mL} \mathrm{Sm} 60$. NO 2 production was determined by Griess reaction and the cytokine dosages were done by ELISA. Data are shown as the mean \pm SD and are representative of two experiments performed in triplicate. Similar amount of $\mathrm{NO}_{2}$ and cytokines were obtained of cells from non-immunised mice stimulated with Con A.

BALB/c mice $\left(\mathrm{H}-2^{\mathrm{d}}\right)$, antigen-driven cell-proliferative responses were also inhibited by $\mathrm{Sm} 60$ in $\mathrm{LN}$ cells from $\mathrm{C} 3 \mathrm{H}$ mice $\left(\mathrm{H}-2^{\mathrm{k}}\right)$ (data not shown), suggesting that the suppressive effect of Sm60 was independent of mouse MHC haplotype and possibly caused by a common mechanism.

To evaluate the mechanism by which Sm60 inhibited proliferation of $\mathrm{LN}$ cells, we determined if there was any change in the production of some cytokines. When the IL-2 concentrations were quantified in the culture supernatants of LN cells from KLH-immunised mice stimulated with KLH or KLH plus Sm60, we noticed that the presence of Sm60 decreased significantly the synthesis of IL-2 induced in response to KLH (Fig. 2C). No change was detected when other cytokines, such as IFN- $\gamma$ and TGF- $\beta$, were investigated (Figs. 2A and 2B, respectively). These results suggest that the inhibitory effect of Sm60 on the lymphoproliferation may be mediated by its effect on IL-2 production. To address this issue as well as the other possibility that the effect of Sm60 could be dependent on its CRD, since it is a mannosebinding lectin we added exogenous mouse IL-2 at the concentration of $10 \mathrm{ng} / \mathrm{mL}$ or specific monosaccharide $\alpha$ methyl-mannoside, respectively, to the cultures that had been incubated with Sm60. As shown in Fig. (3), no reversion of inhibitory effect of Sm60 was observed even at the highest concentration of carbohydrate $(50 \mathrm{mM})$ (Fig. 3A). In contrast, Sm60-induced suppression was completely abrogated by the addition of exogenous IL-2 on either antigen- (Fig. 3B) or mitogen-driven cell-proliferative response (Fig. 3C), thereby circumventing the block. These results clearly suggested that the in vitro suppression of lymphoproliferation induced by Sm60 could be ascribed to its effect on IL-2 production and that the CRD of the Sm60 was not involved in the phenomenon.

The inhibition of IL-2 synthesis by parasites appears to play a very important role in the pathology of the infections caused by these organisms [21]. In this context, Sm60 appears to act similar to glycoproteins from other pathogens such as the membrane mucin $\mathrm{AgC10}$ from Trypanosoma cruzi [22] that have a potent inhibitory effect on T lymphocyte proliferation and cytokine production. In the similar way, Matsui [23] demonstrated that a purified substance of 87-kDa from Salmonella typhimurium, termed S. typhimurium-derived inhibitor of T-cell proliferation (STI), appeared to be responsible for immunosuppression of T-cells in Salmonella-infected mice. The suppression of T-cell proliferation by STI involved T-cell nonresponsiveness to IL-2 [24] and inhibition of IL-2 receptor (IL-2R) $\gamma$ chain expression [25]. Unlike Sm60, STI-induced suppression was not reversed by addition of exogenous IL-2 in culture [24], probably because there was low expression of IL-2R on T- cell surface. These contrasting results suggest a distinct mechanism of action for STI and Sm60. Another possible pathway of proliferative activity suppression is given by an excreted factor (EF) derived from culture medium of Leishmania major that was also found to suppress Con Ainduced polyclonal activation of mouse $\mathrm{T}$ cells as well as proliferation of KLH-primed T cells [26]. In this case, the IL-2 secretion was not diminished, only the expression of IL2 receptor (IL-2R) on T cell surface. Thus, the detailed reasons for this phenomenon cannot be determined from the results of the present study and the mechanism(s) involved in this process remain to be elucidated.
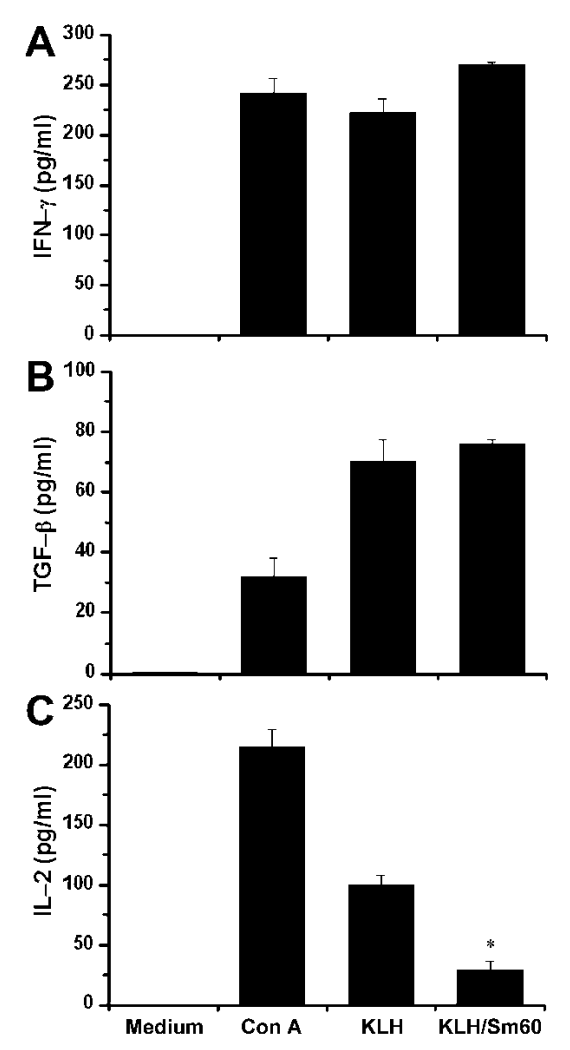

Fig. (2). Sm60 decreased the production of IL-2, but not IFN- $\gamma$ and TGF- $\beta$. Popliteal lymph node cells $\left(2 \times 10^{6} / \mathrm{mL}\right)$ from BALB/c mice immunised with KLH in the footpad were cultured with either Con A $(2 \mu \mathrm{g} / \mathrm{mL})$ or $\mathrm{KLH}(10 \mu \mathrm{g} / \mathrm{mL})$ in the presence or absence of Sm60 $(10 \mu \mathrm{g} / \mathrm{mL})$, for $48 \mathrm{~h}$. Results are the means of IFN- $\gamma(\mathbf{A})$, TGF- $\beta$ (B) and IL-2 (C) concentration \pm SD in triplicate wells. Asterisk indicates significant difference $(P<0.05)$ from value for group stimulated only with KLH. Each sample was assayed in duplicate and the data reported are the result of two independent experiments. 


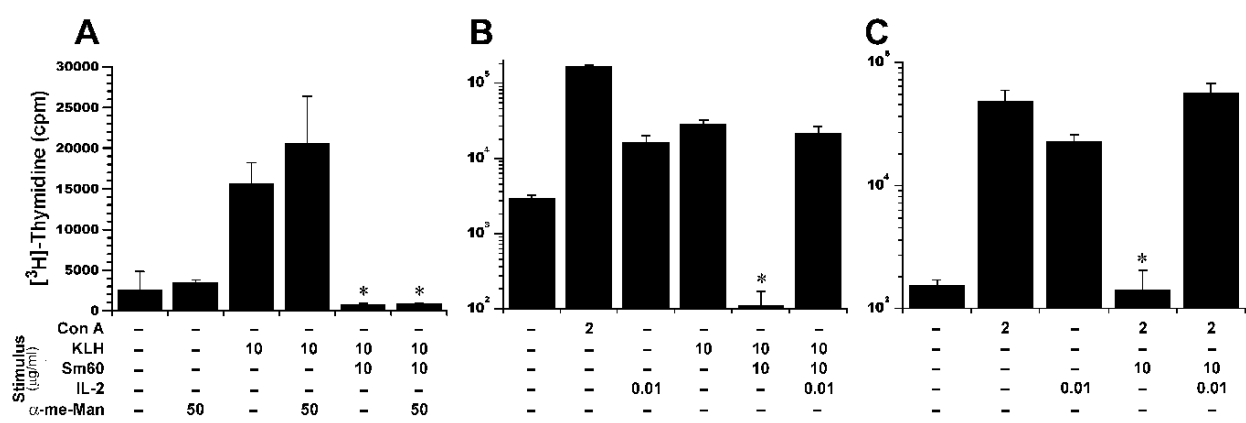

Fig. (3). Exogenous IL-2, but not $\alpha$-methyl-mannoside, is able to reverse the inhibitory effect of Sm60 on the polyclonal or specific proliferation response. Popliteal lymph node cells $\left(2 \times 10^{6} / \mathrm{mL}\right)$ from BALB/c mice immunised with KLH in the footpad (A and B) or nonimmunised $(\mathbf{C})$ were cultured with different stimuli, as indicated on the figure, for $72 \mathrm{~h}$. Proliferative response was determined by $\left[{ }^{3} \mathrm{H}\right]-$ thymidine uptake. Data are reported as the mean \pm standard deviation for three mice per group preformed in triplicate. Results are representative of two independent experiments. ${ }^{*} P<0.05$ compared to groups stimulated with: (panel A) only KLH or KLH plus $\alpha$-methyl-mannoside, (panel B) only Con A, IL-2 or KLH, or KLH plus Sm60 and IL-2, and (panel C) only Con A or IL-2, or Con A plus Sm60 and IL-2.

The potent inhibitory effects of Sm60 on lymphocyte proliferation and IL-2 production might characterise Sm60 as an important immunomodulatory molecule during $S$. mansoni host invasion. The immune interactions that are necessary to eradicate invasive helminth parasites are extremely complex and likely require both humoral and cell-mediated components of the immune system [27]. In S. mansoni infection of mice, initial Th0/Th1-cell responses give way first to pro-inflammatory Th2-cell responses, followed by a decline in parasite-specific T-cell responses in a more regulated environment. The prominence of IL-10 as a crucial mediator of regulation in parasite infections has long been recognized $[28,29]$, particularly for its role in attenuating pathogenesis. Interestingly, despite the protection outcome, no IL-10 production was detected in popliteal lymph node cells cultured with Sm60.

In spite of the Sm60 location, further studies are required to address the issues of surface antigen exposure to know about its accessibility in the tegument, which is of paramount importance when selecting target molecules for vaccines and drugs. One example of accessible antigen is $\mathrm{Sm} 23$, a tetraspanin integral membrane protein from $S$. mansoni tegument [30], which is anchored to the outer membrane, truly exposes its large extracellular loops on the worm surface and has demonstrated efficacy as a vaccine in mice [31-33]. Nevertheless, Sm60 is of particular interest as a potential vaccine because it is also found as a secreted protein [12]. Since Sm60 showed immunosuppressive activity and this property can be used as an addition escape mechanism by $S$. mansoni, Sm60 is suggested to play an important role in schistosomiasis pathogenesis.

\section{ACKNOWLEDGEMENTS}

We thank Ms. Vânia Fernandes and Mrs. Olinda M.B. Previlato for technical assistance. We are grateful to Prof. Dr. Lewis Joel Greene and Prof. Dr. José Cesar Rosa for amino acid analysis and Prof. Dr. Maria Cristina Roque A. Barreira for valuable discussions.

\section{REFERENCES}

[1] Chitsulo, L.; Engels, D.; Montresor, A.; Savioli, L. The global status of schistosomiasis and its control. Acta Trop., 2000, 77(1), 41-51.

[2] Skelly, P. J.; Wilson, R. A. Making sense of the schistosome surface. Adv. Parasitol., 2006, 63, 185-284.
[3] Gabius, H. J. Cell surface glycans: the why and how of their functionality as biochemical signals in lectin-mediated information transfer. Crit. Rev. Immunol., 2006, 26(1), 43-79.

[4] Lis, H.; Sharon, N. Lectins: carbohydrate-specific proteins that mediate cellular recognition. Chem. Rev., 1998, 98, 637-674.

[5] Dodd, R. B.; Drickamer, K. Lectin-like proteins in model organisms: implications for evolution of carbohydrate-binding activity. Glycobiology, 2001, 11(5), 71R-79R.

[6] Sharon, N.; Lis, H. History of lectins: from hemagglutinins to biological recognition molecules. Glycobiology, 2004, 14(11), 53R$62 \mathrm{R}$.

[7] Horák, P.; Van Der Knaap, W. P. W. Lectins in snail-trematode immune interactions: a review. Folia Parasitol., 1997, 44, 161-172.

[8] Mikes, L.; Zidkova, L.; Kasny, M.; Dvorak, J.; Horak, P. In vitro stimulation of penetration gland emptying by Trichobilharzia szidati and $T$. regenti (Schistosomatidae) cercariae. Quantitative collection and partial characterization of the products. Parasitol. Res., 2005, 96(4), 230-241.

[9] Mikes, L.; Horák, P. A protein with lectin activity in penetration glands of Diplostomum pseudospathaceum cercariae. Int. J. Parasitol., 2001, 31(3), 245-252.

[10] Mikes, L.; Man, P. Purification and characterization of a saccharide-binding protein from penetration glands of Diplostomum pseudospathaceum-a bifunctional molecule with cysteine protease activity. Parasitology, 2003, 127, 69-77.

[11] Trottein, F.; Nutten, S.; Papin, J. P.; Leportier, C.; PoulainGodefroy, O.; Capron, A.; Capron, M. Role of adhesion molecules of the selectin-carbohydrate families in antibody-dependent cellmediated cytoxicity to schistosome targets. J. Immunol., 1997, 159(2), 804-811.

[12] Coelho-Castelo, A. A.; Panunto-Castelo, A.; Moreno, A. N.; DiasBaruffi, M.; Jamur, M. C.; Oliver, C.; Roque-Barreira, M. C.; Rodrigues, V. Sm60, a mannose-binding protein from Schistosoma mansoni with inflammatory property. Int. J. Parasitol., 2002, 32(14), 1747-1754.

[13] Bordier, C. Phase separation of integral membrane proteins in triton X-114 solution. J. Biol. Chem., 1981, 256(4), 1604-1607.

[14] Bidlingmeyer, B. A.; Cohen, S. A.; Tarvin, T. L. Rapid analysis of amino acids using pre-column derivatization. J. Chromatogr., 1984, 336(1), 93-104.

[15] Ouaissi, M. A.; Auriault, C.; Santoro, F.; Capron, A. Interaction between Schistosoma mansoni and the complement system: role of IgG Fc peptides in the activation of the classical pathway by schistosomula. J. Immunol., 1981, 127(4), 1556-1559.

[16] Auriault, C.; Ouaissi, M. A.; Torpier, G.; Eisen, H.; Capron, A. Proteolytic cleavage of IgG bound to the Fc receptor of Schistosoma mansoni schistosomula. Parasite Immunol., 1981, 3(1), 3344.

[17] Maizels, R. M.; Bundy, D. A.; Selkirk, M. E.; Smith, D. F.; Anderson, R. M. Immunological modulation and evasion by helminth parasites in human populations. Nature, 1993, 365(6449), 797805.

[18] Maizels, R. M.; Yazdanbakhsh, M. Immune regulation by helminth parasites: cellular and molecular mechanisms. Nat. Rev. Immunol., 2003, 3(9), 733-744. 
[19] Curwen, R. S.; Ashton, P. D.; Johnston, D. A.; Wilson, R. A. The Schistosoma mansoni soluble proteome: a comparison across four life-cycle stages. Mol. Biochem. Parasitol., 2004, 138(1), 5766.

[20] Smyth, D.; McManus, D. P.; Smout, M. J.; Laha, T.; Zhang, W.; Loukas, A. Isolation of cDNAs encoding secreted and transmembrane proteins from Schistosoma mansoni by a signal sequence trap method. Infect. Immun., 2003, 71(5), 2548-2554.

[21] Fresno, M.; Kopf, M.; Rivas, L. Cytokines and infectious diseases. Immunol. Today, 1997, 18(2), 56-58.

[22] Alcaide, P.; Fresno, M. The Trypanosoma cruzi membrane mucin $\mathrm{AgC10}$ inhibits $\mathrm{T}$ cell activation and IL-2 transcription through Lselectin. Int. Immunol., 2004, 16(10), 1365-1375.

[23] Matsui, K. A purified protein from Salmonella typhimurium inhibits proliferation of murine splenic anti-CD3 antibody-activated T-lymphocytes. FEMS Immunol. Med. Microbiol., 1996, 14(2-3), 121-127.

[24] Matsui, K. Purification of a product from Salmonella typhimurium with the ability to inhibit mitogen-induced proliferation of murine splenic T-lymphocytes. FEMS Immunol. Med. Microbiol., 1996, 13(2), 155-160.

[25] Matsui, K.; Arai, T. Salmonella infection-induced non-responsiveness of murine splenic T-lymphocytes to interleukin-2 (IL-2) involves inhibition of IL-2 receptor gamma chain expression. FEMS Immunol. Med. Microbiol., 1998, 20(3), 175-180.

[26] Isakov, N.; Tamir, A.; el-On, J. Suppression of antigen-specific T cell responses by Leishmania major excreted factor: inhibition of activation signals linked to the $\mathrm{T}$ cell antigen receptor and interleukin 2 receptor. Isr. J. Med. Sci., 1994, 30(9), 673-679.
[27] Wynn, T. A.; Hoffmann, K. F. Defining a schistosomiasis vaccination strategy - is it really Th1 versus Th2? Parasitol. Today, 2000, 16(11), 497-501.

[28] Pearce, E. J.; Basch, P. F.; Sher, A. Evidence that the reduced surface antigenicity of developing Schistosoma mansoni schistosomula is due to antigen shedding rather than host molecule acquisition. Parasite Immunol., 1986, 8(1), 79-94.

[29] Sher, A.; Gazzinelli, R. T.; Oswald, I. P.; Clerici, M.; Kullberg, M.; Pearce, E. J.; Berzofsky, J. A.; Mosmann, T. R.; James, S. L.; Morse, H. C. 3rd, Role of T-cell derived cytokines in the downregulation of immune responses in parasitic and retroviral infection. Immunol. Rev., 1992, 127, 183-204.

[30] Harn, D. A.; Mitsuyama, M.; Huguenel, E. D.; David, J. R. Schistosoma mansoni: detection by monoclonal antibody of a 22,000 dalton surface membrane antigen which may be blocked by host molecules on lung stage parasites. J. Immunol., 1985, 135(3), 21152120.

[31] Braschi, S.; Curwen, R. S.; Ashton, P. D.; Verjovski-Almeida, S.; Wilson, A. The tegument surface membranes of the human blood parasite Schistosoma mansoni: a proteomic analysis after differential extraction. Proteomics, 2006, 6(5), 1471-1482.

[32] Da'dara, A. A.; Skelly, P. J.; Wang, M. M.; Harn, D. A. Immunization with plasmid DNA encoding the integral membrane protein, Sm23, elicits a protective immune response against schistosome infection in mice. Vaccine, 2001, 20(3-4), 359-369.

[33] Ribeiro de Jesus, A.; Araujo, I.; Bacellar, O.; Magalhaes, A.; Pearce, E.; Harn, D.; Strand, M.; Carvalho, E. M. Human immune responses to Schistosoma mansoni vaccine candidate antigens. Infect. Immun., 2000, 68(5), 2797-2803.

(C) Coelho-Castelo et al.; Licensee Bentham Open.

This is an open access article licensed under the terms of the Creative Commons Attribution Non-Commercial License (http://creativecommons.org/licenses/by$\mathrm{nc} / 3.0 /$ ) which permits unrestricted, non-commercial use, distribution and reproduction in any medium, provided the work is properly cited. 